\title{
Epidemiological Data on Anaphylaxis in French Emergency Departments
}

Corriger $\mathrm{J}^{1,2}$, Beaudouin $\mathrm{E}^{1}$, Rothmann $\mathrm{R}^{3}$, Penven $\mathrm{E}^{4,5}$, Haumonte $\mathrm{Q}^{1}$, Thomas $\mathrm{H}^{1}$, Picaud $\mathrm{J}^{1}$, Nguyen-Grosjean VM${ }^{1}$, Corriger-Ippolito $\mathrm{J}^{5,6}$, Braun $\mathrm{F}^{3}$, De Talancé $\mathrm{M}^{7}$, Auburtin $\mathrm{B}^{8}$, Atain-Kouadio $\mathrm{P}^{6}$, Borsa-Dorion $A^{9}$, Baugnon $D^{10}$, De Carvalho $\mathrm{M}^{11}$, Jaussaud $\mathrm{R}^{2}$, Nguyen-Thi $\mathrm{PL}^{12}$, Bollaert $\mathrm{PE}^{13}$, Demoly $\mathrm{P}^{14}$, Tanno $\mathrm{LK}^{14}$

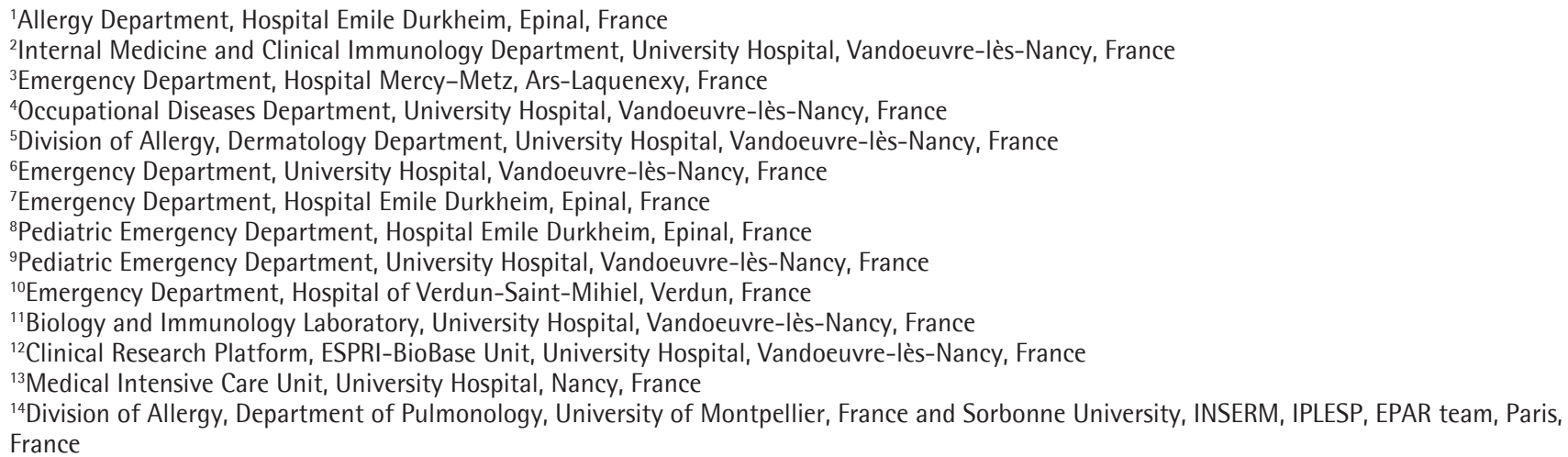

J Investig Allergol Clin Immunol 2019; Vol. 29(5): 357-364

doi: $10.18176 /$ jiaci.0348

\section{Abstract}

Background: Although anaphylaxis has been considered a priority public health issue in the world allergy community, epidemiological data on morbidity and mortality remain suboptimal. We performed the first multicenter epidemiological study in French emergency departments (EDs). The study covered 7 EDs over a period of 1 year. The objectives were to identify areas that are amenable to change and to support ongoing national and international efforts for better diagnosis, management, and prevention of anaphylaxis.

Methods: Ours was a descriptive study based on data routinely reported to French institutional administrative databases from 7 French public health institutions in the Lorraine region between January and December 2015. Data were collected based on the anaphylaxisrelated codes of the International Classification of Diseases (ICD)-10, and cases were clinically validated as anaphylaxis.

Results: Of the 202079 admissions to the EDs, 4817 had anaphylaxis-related codes; of these, 323 were clinically validated as anaphylaxis. Although $45.8 \%$ were severe, adrenaline was prescribed in only $32.4 \%$ of cases. Of the 323 cases, $57.9 \%$ were subsequently referred for an allergy work-up or evaluation (after or during hospitalization), and 17.3\% were prescribed autoinjectable epinephrine.

Conclusion: Our results highlight an urgent need for improved public health initiatives with respect to recognition and treatment of anaphylaxis. We flag key problems that should be managed in the coming years through implementation of national and international actions.

Key words: Anaphylaxis. Emergency. Epidemiology. International Classification of Diseases (ICD). Management

\section{Resumen}

Antecedentes: La anafilaxia es un problema prioritario de salud pública en la comunidad mundial alergológica. Sin embargo, los datos epidemiológicos disponibles de morbilidad y mortalidad son mejorables. Presentamos el primer estudio epidemiológico multicéntrico, realizado en siete departamentos de urgencias franceses durante un año, que tuvo como objetivo identificar las cuestiones relevantes para lograr cambios en futuras estrategias, nacionales e internacionales, que deriven en un mejor diagnóstico, tratamiento y prevención de la anafilaxia.

Métodos: Se trata de un estudio descriptivo que utilizó la información proveniente de las bases de datos de siete instituciones francesas de salud pública, de la región de Lorena, desde enero hasta diciembre de 2015. Se buscaron nomenclatura y códigos relacionados con la anafilaxia, de la Clasificación Internacional de Enfermedades (CIE-10), y los pacientes fueron validados clínicamente como casos de anafilaxia. Resultados: De los 202.079 ingresos en urgencias, 4.817 tenían códigos relacionados con la anafilaxia CIE-10, 323 de los cuales se validaron clínicamente con el diagnóstico de anafilaxia. Aunque el 45,8\% presentó criterios de gravedad, la adrenalina se prescribió 
solo en el 32,4\% de estos casos. En total, 323 casos, el 57,9\%, se remitieron posteriormente para un estudio o evaluación alergológica (después o durante la hospitalización) y el 17,3\% recibió una receta de adrenalina autoinyectable.

Conclusión: Según los resultados de este estudio, existe una necesidad urgente e imperiosa de mejorar los planes de salud pública respecto al reconocimiento y tratamiento de la anafilaxia. Los problemas clave detectados en este trabajo, señalan el camino de la toma de decisiones e implementación de acciones de mejora, nacionales e internacionales, para una mejor atención de los pacientes con anafilaxia.

Palabras clave: Anafilaxia. Urgencias. Epidemiología. Clasificación Internacional de Enfermedades (CIE). Tratamiento.

\section{Introduction}

Anaphylaxis is an acute, severe, life-threatening generalized or systemic hypersensitivity reaction that requires rapid recognition and treatment [1]. It may present as very different combinations of symptoms, and apparently mild signs may unpredictably progress to fatal shock. The recognition of anaphylaxis is hampered, in part, by variability in diagnostic criteria. Consequently, administration of appropriate treatment is delayed, thus increasing the risk of death. Anaphylaxis is a recognized cause of death in all age groups.

Although this condition is considered a priority public health issue in the world allergy community, epidemiological data on morbidity and mortality remain suboptimal. The frequency of anaphylaxis in the emergency department (ED) has been reported to range from $0.04 \%$ to $0.5 \%$ of visits [2-10]. This remarkable variability is related to factors such as differences between populations and EDs, difficulty recognizing at-risk and anaphylactic patients, and the methodology applied to calculate rates.

In 2017, Tanno et al [1] reported a local incidence rate of 32 per 100000 person-years in hospitalized patients in Montpellier, France [11] and a national mortality rate of $0.83(0.80-0.88)$ [12]. However, there are currently no epidemiological studies on the morbidity of anaphylaxis in French EDs.

Ascertaining how anaphylaxis is diagnosed and treated nationally and worldwide is an important preliminary step towards the development of public health strategic action plans to identify and resolve key issues. We proposed a 1-year multicenter epidemiological study in 7 French EDs covering a population of 953552 inhabitants in order to identify key areas for change and to support ongoing national and international efforts for better diagnosis, management, and prevention of anaphylaxis.

\section{Methods}

\section{Data Sources and Case Definition}

Ours was a descriptive study using ED data routinely reported to French institutional administrative databases. The French public hospital structure uses a system of coding alongside the length of hospital stay to determine the chargeable cost of care per patient for purposes of reimbursement. The coding system used is the World Health Organization (WHO) International Classification of Diseases
(ICD), currently ICD-10 [13]. Coding is based on review of case reports by professional coders, who take into account diagnosis, procedures, and other events reported by the care team. The data are submitted to be included in national health statistics and are used for research and planning. Since French public health institutions serve as references for patients in the regions where they located, patients are generally referred to these hospitals.

In this study, we evaluated data from 7 EDs in institutions from the University of the Lorraine urban region between January and December 2015. Data were retrieved in January 2016. Lorraine is an administrative area in the northeast of France with 32 public healthcare institutions of different complexities.

Of the 202079 ED admissions recorded during the year 2015 , we accessed all consecutive files in which the primary

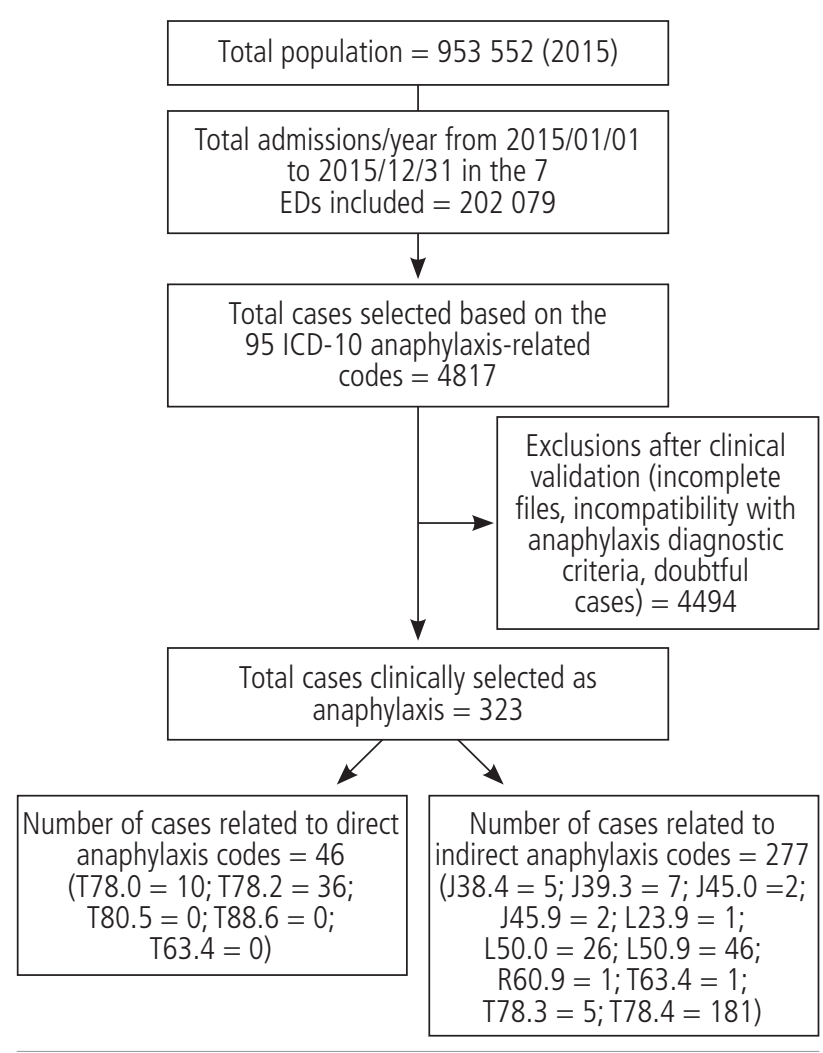

Figure. Flow chart showing patient selection and inclusion based on the International Classification of Diseases. 
cause of admission was assigned an anaphylaxis-related $I C D$-10 code (Table 1). Incidence was calculated based on the number of admissions during 2015. Of the 4817 cases coded as being anaphylaxis-related, $323(6.7 \%)$ were clinically validated retrospectively as anaphylaxis by 2 independent allergists and based on the current accepted international diagnostic criteria and criteria for the characterization of anaphylaxis $[1,14,15]$. Doubtful cases were discussed openly with the coauthors (Figure). We then reviewed the corresponding ICD-10 codes for the clinically validated cases.

Table 1. International Classification of Diseases (ICD)-10 Anaphylaxis-Related Codes Used in the Initial Selection of Cases ( $n=95)$

\begin{tabular}{|c|c|c|}
\hline \multicolumn{2}{|c|}{ ICD-10 codes (2016) } & \multirow[t]{2}{*}{ Description } \\
\hline Category & Extension & \\
\hline D69 & 0 & Allergic purpura \\
\hline $\mathrm{H} 10$ & $.1,3,9$ & Conjunctivitis \\
\hline I46 & $.0,9$ & Cardiac arrest \\
\hline I95 & .8 & Other hypotension \\
\hline $\mathrm{J} 30$ & $.1-4$ & Allergic rhinitis \\
\hline $\mathrm{J} 38$ & $.4,5$ & Edema of larynx and laryngeal spasm \\
\hline J39 & .3 & Upper respiratory tract hypersensitivity reaction \\
\hline $\mathrm{J} 45$ & $.0,1,8,9$ & Asthma \\
\hline $\mathrm{J} 46$ &. $\mathrm{X}$ & Status asthmaticus and acute severe asthma \\
\hline $\mathrm{J} 67$ & $.8,9$ & Hypersensitivity pneumonitis due to other or unspecified organic dust \\
\hline K52 & .2 & Allergic and dietetic gastroenteritis and colitis \\
\hline K90 & .4 & Malabsorption due to intolerance or hypersensitivity \\
\hline L03 & .9 & Cellulitis, located edema or erythema \\
\hline L20 & $.8,9$ & Atopic dermatitis \\
\hline L23 & $.0-9$ & Allergic contact dermatitis \\
\hline L24 & $.0-9$ & Irritant contact dermatitis \\
\hline L25 & $.0-5,8,9$ & Unspecified contact dermatitis \\
\hline L27 & $.0-2,8,9$ & Dermatitis or skin eruptions due to substances taken internally, drugs and medicaments \\
\hline L30 & $.8,9$ & Dermatitis and eczema \\
\hline L50 & $.0-9(\operatorname{excl~3,7)}$ & Urticaria \\
\hline L53 & $.0,9$ & Toxic or unspecified erythema \\
\hline L56 & $.0-3$ & Drug phototoxic or photoallergic responses, photocontact dermatitis and solar urticaria \\
\hline M31 & .0 & Hypersensitivity angiitis \\
\hline M36 & .4 & Arthropathy in hypersensitivity reactions \\
\hline O29 & .3 & Toxic reaction to local anesthesia during pregnancy \\
\hline $\mathrm{O} 74$ & .4 & Toxic reaction to local anesthesia during labor and delivery \\
\hline O89 & .3 & Toxic reaction to local anesthesia during puerperium \\
\hline $\mathrm{R} 21$ &. $\mathrm{X}$ & Rash and other nonspecific skin eruption \\
\hline R60 & $.1,9$ & Generalized or unspecified edema \\
\hline $\mathrm{T} 78$ & .0 & Anaphylactic shock due to adverse food reaction \\
\hline $\mathrm{T} 78$ & .1 & Other adverse food reactions \\
\hline $\mathrm{T} 78$ & .2 & Anaphylactic shock, unspecified \\
\hline $\mathrm{T} 78$ & .3 & Quincke edema \\
\hline $\mathrm{T} 78$ & .4 & Allergic reaction, unspecified \\
\hline $\mathrm{T} 80$ & .5 & Anaphylactic shock due to serum \\
\hline $\mathrm{T} 80$ & .6 & Other serum reactions \\
\hline $\mathrm{T} 81$ & $.1,6$ & Shock or acute reaction resulting from a procedure or a substance left during a procedure \\
\hline T88 & .6 & Anaphylactic shock due to adverse effect of correct drug properly administered \\
\hline Z01 & .5 & Diagnostic skin and sensitization tests (allergy tests) \\
\hline $\mathrm{Z51}$ & .6 & Desensitization to allergens \\
\hline
\end{tabular}


Table 2. Cases of Anaphylaxis: Characteristics and Demographic Data

\begin{tabular}{|c|c|c|c|c|}
\hline Demographic Data & $\begin{array}{c}\text { Children }(<18 \mathrm{y}) \\
\mathrm{n}=106(32.8 \%)\end{array}$ & $\begin{array}{l}\text { Adults }(\geq 18 y) \\
n=217(67.2 \%)\end{array}$ & $\begin{array}{c}\text { Total }(0-88 \mathrm{y}) \\
\mathrm{N}=323(100.0 \%)\end{array}$ & $P$ Value ${ }^{\mathrm{a}}$ \\
\hline \multicolumn{5}{|l|}{ Gender } \\
\hline Male & $65(61.3 \%)$ & $119(54.8 \%)$ & $184(57.0 \%)$ & \\
\hline Female & $41(38.7 \%)$ & $98(45.2 \%)$ & $139(43.0 \%)$ & .27 \\
\hline \multicolumn{5}{|l|}{ Manifestations } \\
\hline Cutaneous & $95(89.6 \%)$ & $202(93.1 \%)$ & $297(92.0 \%)$ & .28 \\
\hline Respiratory & $69(65.1 \%)$ & $141(65.0 \%)$ & $210(65.0 \%)$ & .98 \\
\hline Upper airway & $51(48.1 \%)$ & $91(41.9 \%)$ & $142(44.0 \%)$ & .29 \\
\hline Lower airway & $45(42.5 \%)$ & $93(42.9 \%)$ & $138(42.7 \%)$ & .95 \\
\hline \multicolumn{5}{|l|}{ Cardiovascular and/or } \\
\hline loss of consciousness & $36(34.0 \%)$ & $98(45.2 \%)$ & $134(41.5 \%)$ & .06 \\
\hline Gastrointestinal & $47(44.3 \%)$ & $60(27.6 \%)$ & $107(33.1 \%)$ & .002 \\
\hline Biphasic reaction & $8(7.5 \%)$ & $8(3.7 \%)$ & $16(5.0 \%)$ & .13 \\
\hline \multicolumn{5}{|l|}{ Severity } \\
\hline Grade I & $22(20.8 \%)$ & $47(21.7 \%)$ & $69(21.4 \%)$ & .85 \\
\hline Grade II & $37(34.9 \%)$ & $69(31.8 \%)$ & $106(32.8 \%)$ & .58 \\
\hline Grade III & $47(44.3 \%)$ & $99(45.6 \%)$ & $146(45.2 \%)$ & .83 \\
\hline Grade IV & $0(0.0 \%)$ & $2(0.9 \%)$ & $2(0.6 \%)$ & .32 \\
\hline \multicolumn{5}{|l|}{ Cofactors } \\
\hline Asthma & $36(34.0 \%)$ & $25(11.5 \%)$ & $61(18.9 \%)$ & $<.001$ \\
\hline Cardiovascular disease & $3(2.8 \%)$ & $31(14.3 \%)$ & $34(10.5 \%)$ & .002 \\
\hline Alcohol intake & $0(0.0 \%)$ & $11(5.1 \%)$ & $11(3.4 \%)$ & .002 \\
\hline Associated drugs & $1(0.9 \%)$ & $65(30.0 \%)$ & $66(20.4 \%)$ & $<.001$ \\
\hline$\beta$-blockers & $0(0.0 \%)$ & $23(10.6 \%)$ & $23(7.1 \%)$ & $<.001$ \\
\hline NSAIDs or aspirin & $0(0.0 \%)$ & $29(13.4 \%)$ & $29(9.0 \%)$ & $<.001$ \\
\hline ACEIs or ARBs & $0(0.0 \%)$ & $39(18.0 \%)$ & $39(12.1 \%)$ & $<.001$ \\
\hline PPIs & $1(0.9 \%)$ & $20(9.2 \%)$ & $21(6.5 \%)$ & .005 \\
\hline \multicolumn{5}{|l|}{ Etiology } \\
\hline Drugs & $7(6.6 \%)$ & $76(35.0 \%)$ & $83(25.7 \%)$ & .001 \\
\hline ß-Lactams & $2(1.9 \%)$ & $37(17.1 \%)$ & $39(12.1 \%)$ & $<.001$ \\
\hline Other antibiotics & $0(0.0 \%)$ & $8(3.7 \%)$ & $8(2.5 \%)$ & .045 \\
\hline NSAIDs & $2(1.9 \%)$ & $7(3.2 \%)$ & $9(2.8 \%)$ & .49 \\
\hline Radiocontrast agents & $0(0.0 \%)$ & $14(6.4 \%)$ & $14(4.3 \%)$ & .008 \\
\hline Other or unidentified & $3(2.8 \%)$ & $10(4.6 \%)$ & $13(4.0 \%)$ & .45 \\
\hline Food & $82(77.4 \%)$ & $55(25.3 \%)$ & $137(42.4 \%)$ & $<.001$ \\
\hline Peanut and nuts & $29(27.3 \%)$ & $9(4.1 \%)$ & $38(11.8 \%)$ & $<.001$ \\
\hline Hen egg & $6(5.7 \%)$ & $1(0.5 \%)$ & $7(2.1 \%)$ & .003 \\
\hline Cow milk & $9(8.5 \%)$ & $0(0.0 \%)$ & $9(2.8 \%)$ & $<.001$ \\
\hline Fish and meat & $4(3.8 \%)$ & $5(2.3 \%)$ & $9(2.8 \%)$ & 0.45 \\
\hline Shellfish & $2(1.9 \%)$ & $17(7.8 \%)$ & $19(5.9 \%)$ & .03 \\
\hline Other or unidentified & $32(30.2 \%)$ & $23(10.6 \%)$ & $55(17.0 \%)$ & $<.001$ \\
\hline Insect sting & $10(9.4 \%)$ & $65(30.0 \%)$ & $75(23.2 \%)$ & $<.001$ \\
\hline Undetermined & $4(3.8 \%)$ & $21(9.7 \%)$ & $25(7.8 \%)$ & .06 \\
\hline Other & $3(2.8 \%)$ & $0(0.0 \%)$ & $3(0.9 \%)$ & .01 \\
\hline Previous history of anaphylaxis & $28(26.4 \%)$ & $37(17.1 \%)$ & $65(20.1 \%)$ & .049 \\
\hline Serum tryptase measurement & $8(7.5 \%)$ & $33(15.2 \%)$ & $41(12.7 \%)$ & .05 \\
\hline \multicolumn{5}{|l|}{ Treatment } \\
\hline Use of epinephrine & $12(11.3 \%)$ & $44(20.3 \%)$ & $56(17.3 \%)$ & .045 \\
\hline \multicolumn{5}{|l|}{ Administration route } \\
\hline Intravenous & $2(1.9 \%)$ & $20(9.2 \%)$ & $22(6.8 \%)$ & .01 \\
\hline Intramuscular & $5(4.7 \%)$ & $4(1.9 \%)$ & $9(2.8 \%)$ & .14 \\
\hline Subcutaneous & $0(0.0 \%)$ & $5(2.3 \%)$ & $5(1.5 \%)$ & .12 \\
\hline Inhaled & $4(3.8 \%)$ & $7(3.2 \%)$ & $11(3.4 \%)$ & .07 \\
\hline Unknown & $1(0.9 \%)$ & $8(3.7 \%)$ & $9(2.8 \%)$ & .16 \\
\hline \multicolumn{5}{|l|}{ By severity ${ }^{b}$} \\
\hline Grade I & $0(0.0 \%)$ & $0(0.0 \%)$ & $0(0.0 \%)$ & - \\
\hline Grade II & $3(8.1 \%)$ & $5(7.2 \%)$ & $8(7.5 \%)$ & .87 \\
\hline Grade $\geq$ III & $9(19.1 \%)$ & $39(38.6 \%)$ & $48(32.4 \%)$ & .02 \\
\hline Systemic antihistamine & $89(84.0 \%)$ & $195(89.9 \%)$ & $284(87.9 \%)$ & .13 \\
\hline Systemic corticosteroid & $91(85.8 \%)$ & $184(84.8 \%)$ & $275(85.1 \%)$ & .80 \\
\hline
\end{tabular}


Table 2. Cases of Anaphylaxis: Characteristics and Demographic Data

\begin{tabular}{|c|c|c|c|c|}
\hline Demographic Data & $\begin{array}{c}\text { Children }(<18 \text { y) } \\
n=106(32.8 \%)\end{array}$ & $\begin{array}{l}\text { Adults }(\geq 18 \mathrm{y}) \\
\mathrm{n}=217(67.2 \%)\end{array}$ & $\begin{array}{c}\text { Total }(0-88 \text { y) } \\
\mathrm{N}=323(100.0 \%)\end{array}$ & $P$ Value \\
\hline Hospitalization & $31(29.2 \%)$ & $15(6.9 \%)$ & $46(14.2 \%)$ & $<.001$ \\
\hline $\begin{array}{l}\text { Observation period at the } \mathrm{E} \\
<6 \mathrm{~h} 88(83.0 \%) \\
>6 \mathrm{~h} 18(17.0 \%)\end{array}$ & $\begin{array}{c}149(68.7 \%) \\
68(31.3 \%)\end{array}$ & $\begin{array}{c}237(73.4 \%) \\
86(26.6 \%)\end{array}$ & .006 & \\
\hline Referred to the allergist & $78(73.6 \%)$ & $109(50.2 \%)$ & $187(57.9 \%)$ & $<.001$ \\
\hline $\begin{array}{l}\text { Prescription of } \\
\text { autoinjectable epinephrine }\end{array}$ & $26(24.5 \%)$ & $30(13.8 \%)$ & $56(17.3 \%)$ & .02 \\
\hline
\end{tabular}

Abbreviations: ACEI, angiotensin-converting enzyme inhibitors; ARB, angiotensin-2 receptor blockers; NSAID, nonsteroidal anti-inflammatory drugs; $\mathrm{PPI}$, proton pump inhibitor.

a $P$ value for test of equality of proportions.

${ }^{b}$ Ring \& Messmer classification.

\section{Reference Population}

The geographical regions were defined using the official map of France for the year 2014. Data were collected and anonymized after approval by our institutional Advisory Committee on the Treatment of Information on Research in the Field of Health (CCTIRS) [16].

\section{Statistical Analysis}

Data were analyzed using LibreOffice and EpiData. The statistical descriptions included mean, median, and standard deviation for quantitative variables and frequencies and percentages for categorical variables. The group comparisons were made using the $\chi^{2}$ test for categorical variables and the $t$ test for quantitative variables. An analysis of variance (ANOVA) was performed to compare the means of multiple samples. A $P$ value of $<.05$ was considered significant.

\section{Results}

The epidemiological and clinical characteristics of the patients and results for the management of the anaphylactic reactions are summarized in Table 2. In 2015, anaphylaxis was responsible for $0.16 \%$ of ED admissions. Extrapolating to the urban areas covered, the incidence was estimated at 34 per 100000 person-years. Of the 323 patients with clinically confirmed anaphylaxis, $67.2 \%$ were adults aged 18 to 88.4 years, and $32.8 \%$ were children aged 2 months to 18 years. The sex ratio was 1.32 in favor of males. Adults presented mainly drug-induced and insect sting-related anaphylaxis, whereas food was the main trigger in the pediatric population (Table 2). No deaths were reported. A previous history of anaphylaxis was found in $20.1 \%$ and a biphasic reaction in $5.0 \%$ of the patients. Epinephrine was used significantly more often in adults than in children $(P=.045)$. Although $45.8 \%(148 / 323)$ of the patients presented severe anaphylaxis (Ring \& Messmer grade $\geq 3$ ), epinephrine was prescribed in only $32.4 \%(48 / 148)$ of these cases, mostly by intravenous injection (41.7\%), and more often in children than in adults $(P=.02)$. Children were more frequently referred to allergists and received more prescriptions than adults (Table 2). Serum tryptase was measured in $12.7 \%$ of patients, and $60.1 \%$ were kept under observation in hospital for less than 6 hours (median, 4.7 hours).

Of the 323 cases, $57.9 \%$ were subsequently referred for an allergy work-up or evaluation (after or during hospitalization), and $17.3 \%$ were prescribed autoinjectable epinephrine (Table 2). Twenty percent of patients experienced more than 1 episode of anaphylaxis, even after the allergological diagnosis was established $(37 \%$ with exposure to food allergens and $22 \%$ after drug intake).

Concomitant asthma was the only cofactor identified as being significantly $(P<.05)$ associated with more severe (grade $\geq 3$ ) anaphylactic episodes in children (OR, 2.37; $95 \% \mathrm{CI}, 1.04-5.38)$. In adults, the only significantly associated cofactor was use of 1 or more of a series of drugs ( $\beta$-blockers, aspirin and other nonsteroidal anti-inflammatory drugs, angiotensin-converting enzyme inhibitors, angiotensin-2 receptor antagonists, proton pump inhibitors, dipeptidyl peptidase-4 inhibitors, and glucagon-like peptide-1 agonists) (OR, 2.18; 95\%CI, 1.20-3.94). Clinical presentations were influenced by specific factors: concomitant asthma was associated with a higher frequency of lower respiratory tract symptoms (OR, 2.26; 95\% CI, 1.28-3.98), cardiovascular disorders with cardiovascular injury (OR, 2.19; 95\%CI, 1.064.52), and food as a trigger with gastrointestinal manifestations (OR, 1.83; 95\%CI, 1.15-2.92) ( $P<.05$ for all).

Of the 323 confirmed cases of anaphylaxis, only $14.3 \%$ presented anaphylaxis classed as direct according to the ICD-10 codes (Figure).

\section{Discussion}

Ours is the first study to present epidemiological data on the morbidity and management of anaphylaxis in French EDs. We highlight the need to harmonize knowledge of management of anaphylaxis. Awareness of anaphylaxis as a life-threatening medical condition has been increasing in various specialties, 
and recent publications show that it is not as uncommon a condition as previously thought. However, most publications to date consider degrees of severity of anaphylaxis, and the severe forms may still well be considered rare diseases [17]. In the present study, we demonstrated that anaphylaxis was responsible for $0.16 \%$ of ED admissions, with an incidence estimated at 34 per 100000 person-years.

Although injectable epinephrine is currently listed in the WHO list of essential drugs for the treatment of anaphylaxis, our findings were remarkable in that it was rarely prescribed, even in severe cases [18]. This finding is consistent with most recently published data in the field [2-10]. Additionally, a relevant number of patients were hospitalized or kept under observation for a shorter period than recommended [15].

In contrast to most international recommendations [14], we observed that intravenous epinephrine was administered very frequently, despite being responsible for serious complications such as acute pulmonary edema, arrhythmia, and acute coronary events. In addition, we found a reduced proportion of referral to allergists and lack of prescription of epinephrine autoinjectors. We believe that these findings may be associated with uncertainty among physicians about the diagnosis of anaphylaxis, which was defined based on anaphylaxis classed as indirect according to the ICD-10 codes. The recent recognition of allergy as a full specialty paves the way for bilateral collaboration with other specialties and will enhance management of anaphylactic patients.

Particularly striking was the number of patients who presented a second episode of anaphylaxis, even with the allergological diagnosis. Consequently, greater awareness is necessary among patients and caregivers in order to avoid re-exposure to known triggers. Educational efforts will also help to decrease underrecognition of anaphylaxis by patients, caregivers, health professionals, health authorities, and governments. In addition, allergy academies have promoted training programs and publications in the field [1,14,15,19-22].

Serial serum (or plasma) levels of tryptase should be collected to guide the diagnosis of anaphylaxis or to exclude mast cell disorders, which can mimic anaphylaxis. However, these samples have only been collected in a limited number of severe reactions, thus indicating the need for a systematic anaphylaxis action plan. National and international guidelines have been drafted to fill these gaps [14,23-25].

Underreporting or underestimation of anaphylaxis can be explained by the difficulty in coding anaphylaxis deaths under the WHO ICD system. Limited numbers of ICD-10 codes are considered valid for the morbidity and mortality of anaphylaxis [8], as demonstrated in patients diagnosed by direct $I C D-10$ codes for anaphylaxis (46 cases) and indirect anaphylaxis ICD-10 codes (277 cases) (Figure). For this reason, we included additional codes related to manifestations and causes that could resemble or induce anaphylaxis or even allergic reactions (Table 1). Over the last 5 years, a strategic international action plan supported by the Joint Allergy Academies and the WHO [11,17,18,2631] was implemented to update the classifications of allergic conditions for the new edition of the ICD. These efforts resulted in the construction of the new "Allergic and hypersensitivity conditions" section in $I C D-11$ [28,32], with a subsection dedicated exclusively to anaphylaxis. The availability of this new section should enable better morbidity and mortality statistics to be reported.

Recent international achievements have been accompanied by the efforts made since 2014 to recognize allergy as a full academic specialty in France. This will improve the training of health professionals in the field and support quality management of allergic patients. Anaphylaxis, as well as other allergic and hypersensitivity conditions, are systemic disorders that require a multidisciplinary approach [17]. Recognition of allergy as a full specialty will strengthen collaboration with other specialties, thus increasing scientific consistency and awareness.

Our study is the first to report epidemiological data on anaphylaxis in French EDs. It highlights regional differences in the incidence and management of the disease. Although the diagnosis of anaphylaxis is limited by the retrospective nature of the study, all cases were clinically validated manually in order to reduce the number of doubtful cases. Another known limitation is the number of participating EDs and the size of the geographic area studied, which may have affected the epidemiological findings. However, our results confirm national and international efforts for improved diagnosis and management of anaphylaxis. Broader studies are required to increase our knowledge of the epidemiology of anaphylaxis and to support advances in and the use of new classifications of allergic and hypersensitivity conditions. We intend to support the implementation process of $I C D-11$ in order to ensure more accurate and comparable data on the morbidity of anaphylaxis.

In conclusion, there is an urgent need for improved public health initiatives on the recognition and treatment of anaphylaxis. The data presented here are consistent with the findings of the European Anaphylaxis Registry, which concludes that despite clear recommendations, only a small proportion of cases of anaphylaxis are treated with epinephrine [33]. We believe that the present document flags key problems, which may be managed in the coming years through implementation of national and international programs. Strategies to overcome the main barriers in anaphylaxis care should be based on bilateral partnership between allergists and emergency physicians.

\section{Acknowledgments}

We are very grateful to Marcelo De Carvalho for his collaboration and support.

\section{Funding}

Pascal Demoly and Luciana Kase Tanno received an unrestricted Novartis and MEDA/Mylan Pharma grant through the CHRUM administration.

\section{Conflicts of Interest}

The authors declare that they have no conflicts of interests. 


\section{References}

1. Sampson HA, Munoz-Furlong A, Campbell RL, Adkinson NF Jr, Bock SA, Branum A, et al. Second symposium on the definition and management of anaphylaxis: summary report - Second National Institute of Allergy and Infectious Disease/Food Allergy and Anaphylaxis Network Symposium. J Allergy Clin Immunol. 2006;117:391-7.

2. Smit D V, Cameron PA, Rainer TH. Anaphylaxis presentations to an emergency department in Hong Kong: incidence and predictors of biphasic reactions. J Emerg Med. 2005;28:3818.

3. Bellou A, Manel J, Samman-Kaakaji H, de Korwin JD, MoneretVautrin DA, Bollaert PE, et al. Spectrum of acute allergic diseases in an emergency department: an evaluation of one years' experience. Emerg Med. 2003;15:341-7.

4. Brown AF, McKinnon D, Chu K. Emergency department anaphylaxis: A review of 142 patients in a single year. J Allergy Clin Immunol. 2001;108:861-6.

5. Campbell RL, Luke A, Weaver AL, St Sauver JL, Bergstralh EJ, Li JT, et al. Prescriptions for self-injectable epinephrine and follow-up referral in emergency department patients presenting with anaphylaxis. Ann Allergy Asthma Immunol. 2008;101:631-6.

6. Beyer K, Eckermann O, Hompes S, Grabenhenrich L, Worm M. Anaphylaxis in an emergency setting - elicitors, therapy and incidence of severe allergic reactions. Allergy. 2012;67:14516.

7. Cianferoni A, Novembre E, Mugnaini L, Lombardi E, Bernardini $R$, Pucci $N$, et al. Clinical features of acute anaphylaxis in patients admitted to a university hospital: an 11-year retrospective review (1985-1996). Ann Allergy Asthma Immunol. 2001;87:27-32.

8. Poachanukoon 0 , Paopairochanakorn C. Incidence of anaphylaxis in the emergency department: a 1-year study in a university hospital. Asian Pac J Allergy Immunol. 2006;24:1116.

9. Alvarez-Perea A, Tomás-Pérez M, Martínez-Lezcano P, Marco G, Pérez D, Zubeldia JM, et al. Anaphylaxis in adolescent/adult patients treated in the emergency department: Differences between initial impressions and the definitive diagnosis. J Investig Allergol Clin Immunol Clin Immunol. 2015;25:288 94.

10. Moro Moro M, Tejedor Alonso MA, Esteban Hernandez J, Mugica Garcia MV, Rosado Ingelmo A, Vila Albelda C. Incidence of anaphylaxis and subtypes of anaphylaxis in a general hospital emergency department. J Investig Allergol Clin Immunol. 2011;21(2):142-9.

11. Tanno LK, Molinari N, Bruel S, Bourrain JL, Calderon MA, Aubas $P$, et al. Field-testing the new anaphylaxis' classification for the WHO International Classification of Diseases-11 revision. Allergy. 2017 May; 72(5):820-6.

12. Pouessel G, Claverie C, Labreuche J, Dorkenoo A, Renaudin JM, Eb $\mathrm{M}$, et al. Fatal anaphylaxis in France: Analysis of national anaphylaxis data, 1979-2011. J Allergy Clin Immunol. 2017 Aug;140(2):610-2.e2.

13. World Health Organization, ICD-10 version 2016 website. Internet; 2016. (Available at: http://apps.who.int/ classifications/icd10/browse/2016/en, Accessed January 2018).

14. Simons FE, Ardusso LR, Bilò $M B$, Cardona $V$, Ebisawa $M$, El-Gamal YM, et al. International consensus on (ICON) Anaphylaxis. World Allergy Organ J. 2014;30;7:9

15. Muraro A, Roberts G, Worm M, Bilo MB, Brockow K, FernandezRivas $M$, et al. Anaphylaxis: guidelines from the European Academy of Allergy and Clinical Immunology. Allergy. 2014 Aug;69(8):1026-45.

16. French High Health Authority - Management after the emergency treatment of a suspicion of anaphylaxis. Internet; 2013. (Available at: https://www.has-sante.fr/portail/ jcms/c_1695744/fr/conduite-a-tenir-apres-le-traitement-durgence-d-une-suspicion-d-anaphylaxie, Accessed January 2018).

17. Tanno LK, Demoly P. One voice for anaphylaxis in France: The vision of the centre of reference in rare diseases. Rev $\mathrm{Fr}$ Allergol. 2017 Dec;57(8):583-7.

18. Tanno LK, Simons FER, Cardona V, Calderon M, SanchezBorges $M$, Sisul JC, et al. Applying prevention concepts to anaphylaxis: a Call for Worldwide Availability of Adrenaline Auto-Injectors. Clin Exp Allergy. 2017 Sep;47(9):1108-14.

19. Panesar SS, Javad S, de Silva D, Nwaru BI, Hickstein L, Muraro $A$, et al. The epidemiology of anaphylaxis in Europe: a systematic review. Allergy. 2013;68:1353-61.

20. Lieberman P, Nicklas RA, Oppenheimer J, et al. The diagnosis and management of anaphylaxis practice parameter: 2010 update. J Allergy Clin Immunol. 2010;126:477-80.

21. Simons FE, Ardusso LR, Bilo MB, El-Gamal YM, Ledford DK, Ring J, et al. World Allergy Organization guidelines for the assessment and management of anaphylaxis. World Allergy Organ J. 2011;4(2):13-37.

22. Brown SG, Mullins RJ, Gold MS. Anaphylaxis: diagnosis and management. Med J Aust. 2006;185(5):283-9.

23. Moneret-Vautrin DA, Renaudin JM, Petit N, Mertes PM, Bellou A. Anaphylaxie sévère: prise en charge concertée entre médecins de l'urgence et allergologues. In: Urgences 2009. Chap. 33:353-61.

24. Gloaguen A, Cesareo E, Vaux J, Valdenaire G, Ganansia 0 , Renolleau $S$, et al. Prise en charge de l'anaphylaxie en médecine d'urgence. Ann Fr Med Urgence. 2016;6:342-64.

25. Mertes PM, Alla F, Trechot P, Auroy Y, Jougla E, Groupe d'Etudes des Reactions Anaphylactoides Peranesthesiques. Anaphylaxis during anesthesia in France: an 8-year national survey. J Allergy Clin Immunol. 2011;7:366-73.

26. Tanno LK, Ganem F, Demoly P, Toscano CM, Bierrenbach AL. Undernotification of anaphylaxis deaths in Brazil due to difficult coding under the ICD-10. Allergy 2012;67:783-9.

27. Tanno LK, Calderon MA, Goldberg BJ, Gayraud J, Bircher AJ, Casale T, et al. Constructing a classification of hypersensitivity/ allergic diseases for ICD-11 by crowdsourcing the allergist community. Allergy. 2015;70:609-15.

28. Tanno LK, Calderon MA, Demoly P; Joint Allergy Academies. New Allergic and Hypersensitivity Conditions Section in the International Classification of Diseases-11. Allergy Asthma Immunol Res. 2016 Jul;8(4):383-8.

29. Tanno LK, Bierrenbach $A L$, Calderon MA, Sheikh A, Simons $F E$, Demoly $P$, et al. Decreasing the undernotification of anaphylaxis deaths in Brazil through the International 
Classification of Diseases (ICD)-11 revision. Allergy. 2017 Jan; $72(1): 120-5$.

30. Tanno LK, Simons FE, Annesi-Maesano I, Calderon MA, Aymé $\mathrm{S}$, Demoly P, et al. Fatal anaphylaxis registries data support changes in the WHO anaphylaxis mortality coding rules. Orphanet J Rare Dis. 2017 Jan 13;12(1):8.

31. Tanno LK, Chalmers RJ, Calderon MA, Aymé S, Demoly P; on behalf the Joint Allergy Academies. Reaching multidisciplinary consensus on classification of anaphylaxis for the eleventh revision of the World Health Organization's (WHO) International Classification of Diseases (ICD-11). Orphanet J Rare Dis. 2017 Mar 16;12(1):53.

32. World Health Organization, ICD-11 Beta Draft website. Internet; 2018. (Available: http://apps.who.int/classifications/ icd11/browse/l-m/en, Accessed January 2018).

33. Grabenhenrich LB, Dölle $S$, Ruëff $F$, Renaudin JM, Scherer $K$, Pföhler $C$, et al. Epinephrine in Severe Allergic Reactions: The European Anaphylaxis Register. J Allergy Clin Immunol Pract. 2018 Nov - Dec;6(6):1898-906.e1.
- Manuscript received June 20, 2018; accepted for publication November 5, 2018.

\section{Jeremy Corriger}

Centre Hospitalier Emile Durkheim d'Epinal

Maison de santé Saint-Jean

31 rue Thiers

88000 Epinal, France

E-mail: jeremy.corriger@hotmail.fr

\section{Luciana Kase Tanno}

Division of Allergy, Department of Pulmonology Hôpital Arnaud de Villeneuve, University Hospital of Montpellier 371, av. du Doyen Gaston Giraud 34295, Montpellier cedex 5, France E-mail: luciana.tanno@gmail.com 